\title{
Tax Progression and Tax Justice
}

\author{
Helmut Becker, Deloitte Touche Tohmatsu, Düsseldorf
}

In many countries income taxes are charged according to progressive tax rates; only a few countries - e.g. USA - restrict themselves to one or two proportional tax rates. Therefore the question may be raised whether or not progressive tax rates are in accordance with tax justice. This first needs a definition of tax justice.

In 1791 in his book on the Wealth of Nations, Adam Smith already described the principle that the citizens have to contribute to the expenses of their state in proportion to their respective abilities'. In the same year the French Declaration of Human Rights demanded in Article 13 that the burden of state expenses 'doit être également répartie entre tous les citoyens en raison de leurs facultés'. From that time on the ability to pay (faculté contributive) became an integrated part of tax justice.

Progressive tax rates, however, have been introduced about 100 years later. In 1889, A.J. Cohen Stuart of the Dutch school of Philosophy who can be called the father of tax progression, justified progressive tax rates by using the idea of marginal utilities. Furthermore, as a result of the virulent struggle between the social classes of those years (Karl Marx died in 1883) progressive tax rates were adopted to compensate for indirect taxes.

Nowadays, experts share the universal consensus that the principle to be taxed according to the ability to pay cannot be used to justify a specific scheme of progression. Progressive tax rates therefore are not based on reviewable reasons but on political decisions aimed only at getting the money needed. In some situations even under the marginal utilities concept proportional tax rates are demanded. And after the worldwide collapse of socialism the old class-war-arguments can no longer be honoured.

It is obvious that someone who earns one million has a higher ability to pay taxes than someone who earns only 100,000 . If, however, there would be a proportional taxation of 30 per cent the first would pay 300,000 , the second only 30,000. The first pays ten times of the amount the second will be charged with. However, he also earns ten times of the second. If income defines the ability to pay, both contribute equally to the expenses of their state.

The defendants of progressive tax rates argue that after taxation the first taxpayer can spend 700,000 , the second only 70,000. If this difference should be equalized the income of one million must be taxed at 93 per cent - a tax rate which everybody regards as confiscatory. Therefore, the disposable after tax income cannot be a valid principle of taxation. Furthermore, not gross income but net after tax income would become the basis for taxation, which would not be logical. All in all, proportional tax rates seem to be closer to tax justice than progressive tax rates ever can be.

However, it has to be considered that most states nowadays include social aspects into their concept of justice. Thus there is a consensus that income required to cover subsistence level needs has to be exempt from all taxation. Beyond the subsistence level a state focused on the welfare of its citizens has to guarantee their basic needs for food, clothing, living, education, etc. As far as this is not provided by the state for free-e.g., for health or education - the citizens have to be supported in covering those expenses by earned income. It is obvious that someone who earns just one unit over the subsistence level cannot contribute in the same proportion as someone who earns just one unit under the ceiling of basic needs. The more the taxpayer is able to sustain his basic needs by earned income the more he can be expected to contribute to state expenses. Therefore, within the zone of income higher than subsistence level but still not fully covering basic needs tax rates have to be progressive. However, once basic needs are covered there is no justification at all for progressive tax rates.

It may be argued that in some countries - e.g., Germany - the tax system already looks like that; within the subsistence level it exempts all income from tax, then applies a zone of progression and ends in proportional taxation. The difference, however, is described by the amounts. The proportional taxation in Germany starts with an income of 120,000 DM for singles and 240,000 DM for couples. It may be difficult to define the limiting range of basic 
needs but one thing is clear: The border range is by far lower than the amounts described above. This means that once basic needs have been covered progressive taxation cannot be justified.

Summarizing it can be stated that:

- tax justice has two main components: the ability to pay tax and a social factor;

- within the subsistence range of income no taxes can be levied;

- exclusively in the following zone in which income should cover basis needs a tax progression is justified;

- beyond that zone higher incomes should only be taxed at proportional tax rates;

- for incomes in excess of basic needs progressive tax rates are no longer justified. 